\title{
Oak Wilt: A Potential Future Threat to Oaks in Florida ${ }^{1}$
}

\author{
Kelly Peacock and Jason Smith ${ }^{2}$
}

\section{Overview:}

Oak decline and mortality in Florida has been the subject of much debate and concern in recent years. Due to the ubiquitous nature of oak species in urban and rural landscapes, their high values as landscape trees, and their perceived long life spans, sick oak trees raise concern. One common killer of oak trees in other areas of the United States is oak wilt. This disease is sometimes suspected as the culprit in oak tree death in Florida; however, oak wilt does not currently occur in the state. This publication provides information on the diagnosis, biology, and management of the disease and should provide guidance for future efforts to identify and manage oak wilt in the state of Florida.

\section{Introduction}

Since its identification in the early 1940s, oak wilt has been considered one of the most important and destructive diseases of oaks (Quercus spp.) in North America. To date, oak wilt has been verified in 24 states. Aside from Texas, oak wilt is largely absent from the Gulf States and presently only occurs as far south as South Carolina on the east coast. However, while the disease is not currently present in Florida, based on the susceptibility of several oaks (including the live oaks, Quercus virginiana and Q. fusiformis) in Texas, there is reason to be concerned should the disease spread into the state.

Oak wilt is caused by the fungal pathogen, Ceratocystis fagacearum (Bretz) Hunt, which invades the water-conducting system (xylem) of oaks. An infected oak produces gums and defensive structures called tyloses within its waterconducting cells in an attempt to inhibit the spread of the fungus; however, these defensive components, in addition to fungal matter, block the movement of water through the sapwood (Beckman et al. 1953, Struckmeyer et al. 1954). The interruption of water movement within an infected tree causes the leaves to droop and die; the characteristic wilt symptoms give the disease its name.

The disease is particularly devastating to red oaks (subgenus Quercus section Lobatae), with mature trees often completely wilting within six to eight weeks after initial introduction of the pathogen into xylem tissues. White oaks (subgenus Quercus section Quercus) are also susceptible to infection, but are generally more tolerant of disease, with the exception being live oaks (Q. virginiana and $Q$. fusiformis).

\section{Signs and Symptoms}

Following tree wilt, $C$. fagacearum may grow out of the sapwood and produce specialized fungal mats just beneath the bark. These mats produce an abundance of spores that move overland to new trees, spreading the disease. In general, mats form during the spring after the tree wilts, depending on wood moisture and air temperature. Mats only form on trees belonging to the red oak group.

The most common and obvious symptom of the disease on red oaks is browning or bronzing of the leaves from the margin inward (Figure 1). Premature defoliation of leaves expressing all stages of wilt symptoms (including green,

1. This document is FOR274, School of Forest Resources and Conservation, UF/IFAS Extension. First published November 2010. Reviewed November 2013. Please visit the EDIS website at http://edis.ifas.ufl.edu.

2. Kelly Peacock, biological scientist, School of Forest Resources and Conservation; and Jason Smith, assistant professor, School of Forest Resources and Conservation, UF/IFAS Extension, Gainesville, 32611. 
symptomless leaves) is common; however, depending on the timing of infection and disease development, leaves may turn brown and remain attached to the tree. Wilt symptoms generally progress from the top of the crown downward, and complete wilt of the tree can occur in as little as four to six weeks. Epicormic shoots (sprouts that emerge from the trunk) sometimes develop from wilted trees, particularly the year following wilt, but these usually wilt and die within the same year. Some infected oaks may exhibit dark streaking in the sapwood, but this appears to be species-and region-dependent.

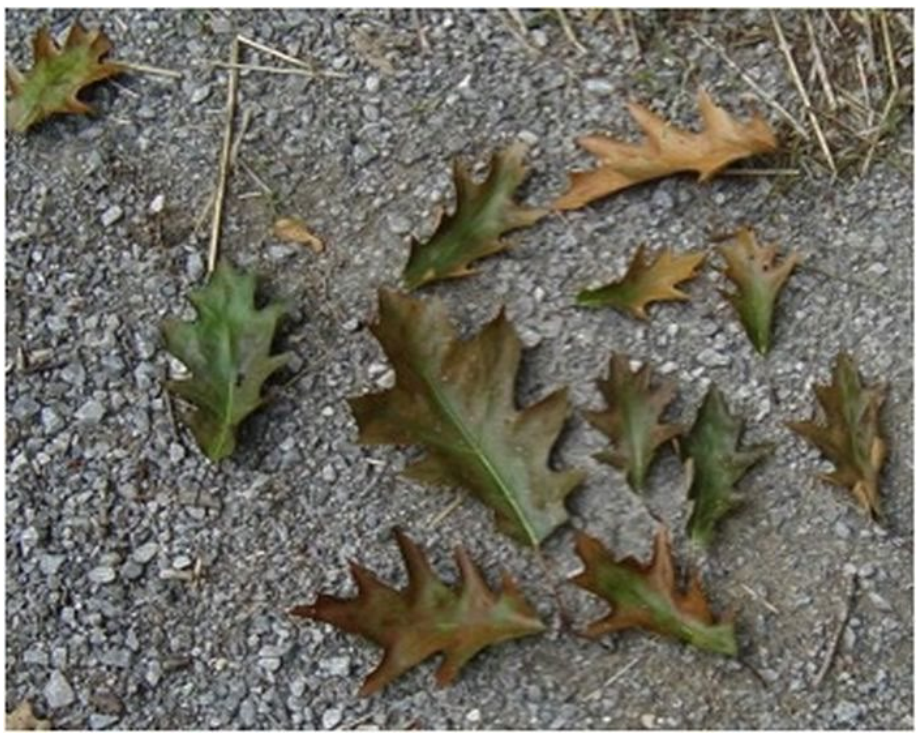

Figure 1. Symptomatic red oak leaves.

Although leaf symptoms are similar, disease progression in white oaks is distinct from disease progression in red oaks. In contrast to the rapid progression of wilt from the upper crown downwards in red oaks, white oaks typically experience branch dieback over a period of several years. White oaks are often able to confine the pathogen, form new wood over the infected wood, and recover (Sachs et al. 1970).

Live oaks (Quercus virginiana and Q. fusiformis), although considered part of the white oak group, are fairly susceptible to wilt and have been severely impacted by the disease in Texas. Live oaks have a xylem morphology that is more similar to that of red oaks, and while up to $20 \%$ of infected individuals may recover, the clonal sprouting habit of these trees makes spread through root systems problematic (Appel 1995a) (Figure 2). Although wilting live oaks also experience premature defoliation (resulting in gradual crown thinning), live oak leaf symptoms are distinct from symptoms in other oaks in that the leaves typically exhibit veinal necrosis (Figure 3).

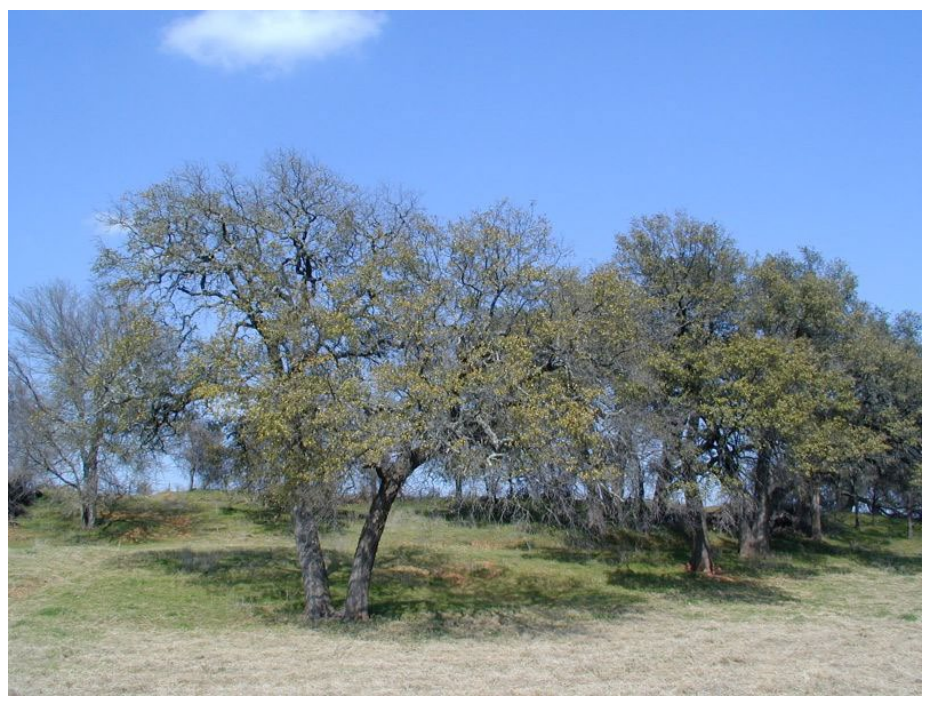

Figure 2. Wilted live oaks: the pathogen moved through a common root system to infect nearby tree.

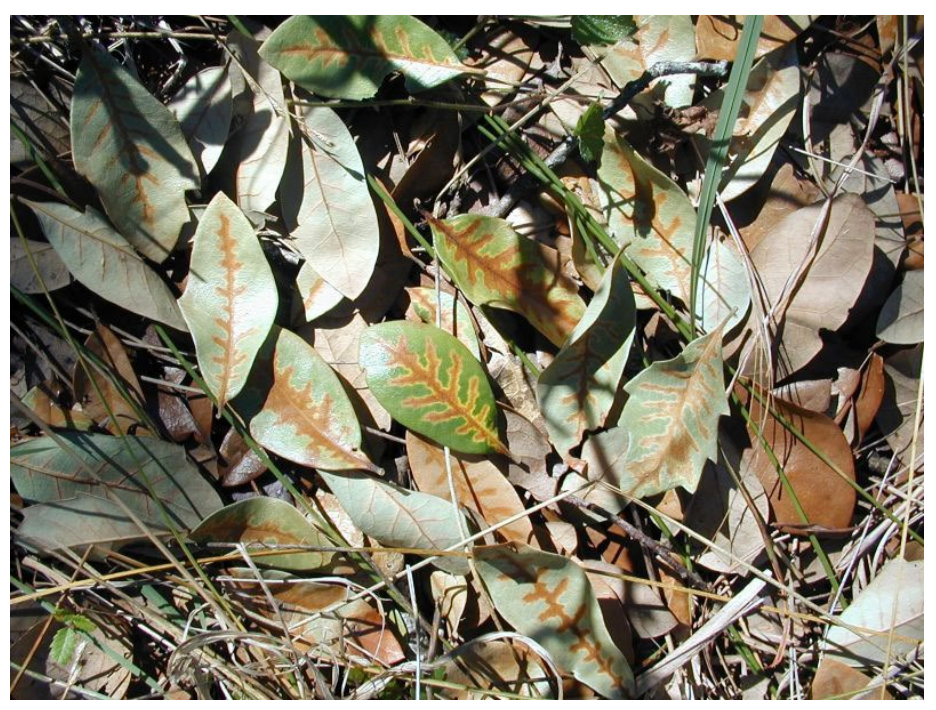

Figure 3. Symptomatic live oak leaves.

Credits: David Appel, Texas A\&M University.

\section{Disease Spread}

Overland spread of the pathogen primarily occurs via sapfeeding nitidulid beetles (Coleoptera:Nitidulidae) (Hayslett et al. 2008). Nitidulid beetles are attracted to the odor produced by both tree wounds (sap of the tree) and fungal mats (which produce a distinctive smell like overripe fruit); therefore, pathogen transmission may occur if a beetle first visits a fungal mat and then visits a wounded, but otherwise healthy, oak. In addition to insect-mediated spread, human movement of the pathogen, via infected firewood, has also been documented.

Local spread of the pathogen is primarily through shared root systems (live oaks) or through root grafts, which form when the roots of two trees of the same species grow into contact. The incidence of root grafting is dependent on 
several factors, including soil type, the diameter of the trees involved, and the distance between these trees (Bruhn et al. 1991). Root transmission accounts for the majority of new cases of wilt and can result in large disease centers that radiate out from an initially infected tree. Aerial surveys are often used to identify these centers.

\section{Control Measures}

Currently, oak wilt control relies on prevention of overland introduction of the pathogen or prevention of root graft spread once the pathogen has been introduced into a stand. Community-based control programs have become a principal means of preventing and minimizing disease spread and occurrence in localized areas (Juzwik et al. 2004, Billings 2008). Control methods consist of sanitation measures, trenching, and fungicide treatment. Sanitation measures include preventing wounds on healthy oaks (or application of wound paint to damaged wood) during the spring and early summer, when vector activity is thought to be greatest, to minimize infection risk (Camilli et al. 2008). In addition, removing wilted trees and completely covering any firewood from diseased trees with plastic helps prevent mat formation and subsequent spore dispersal via insect vectors (O’Brien et al. 2000).

Once the fungus is introduced into an area, control measures focus on prevention of local spread through the roots. Roots (and root grafts) are typically disrupted by making five-foot-deep trenches (Figure 4). The means of trenching (either with a trencher, vibratory plow, or rock saw) often precludes this procedure in many areas because the equipment is large, not readily available, and relatively expensive (Figures 5 and 6). In addition, some residential sites may have buried power, phone, or cable lines, septic tanks, wells, driveways, etc. that would prevent the necessary location of the trench line to create an effective barrier. Chemical injection of the systemic fungicide, propiconazole, may help to protect individual trees (Figures 7 and 8); however, while treatment is often effective for white oaks (including live oaks), there is little success when it is injected into red oaks that are already infected (Osterbauer and French 1992, Osterbauer et al. 1994, Eggers et al. 2005). An additional limitation of chemical treatment is that the fungus is still able to move past a treated tree and into the root system of the next tree. While trenching and chemical injection are useful control measures in some situations, the best means of control is prevention.

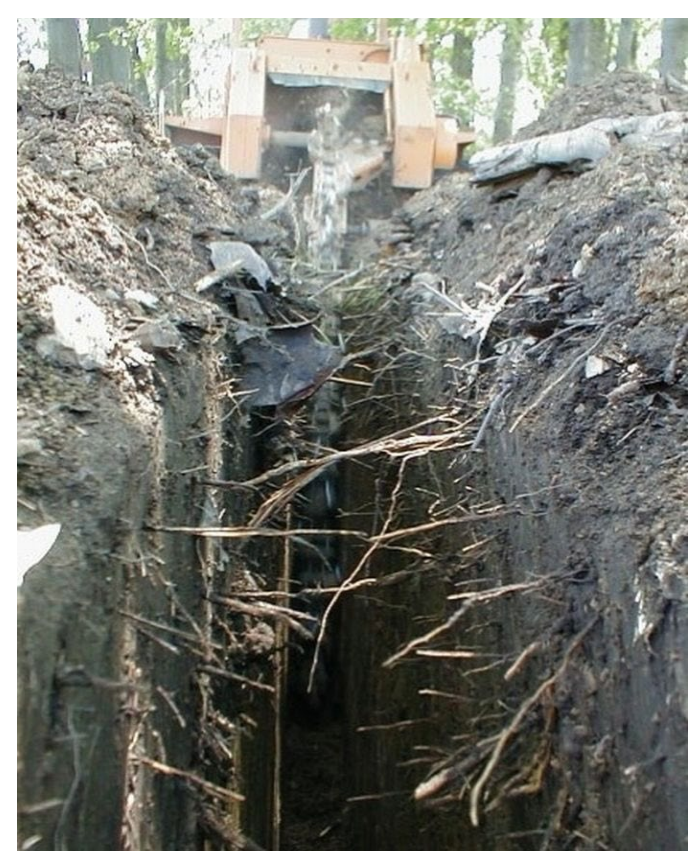

Figure 4. Trench dug as a barrier to root transmission of wilt.

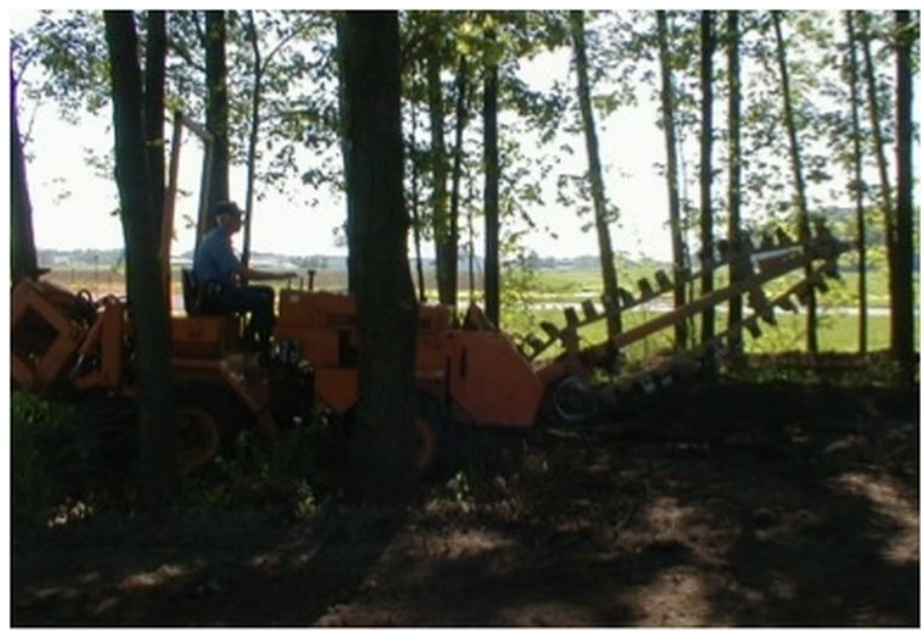

Figure 5. Trencher

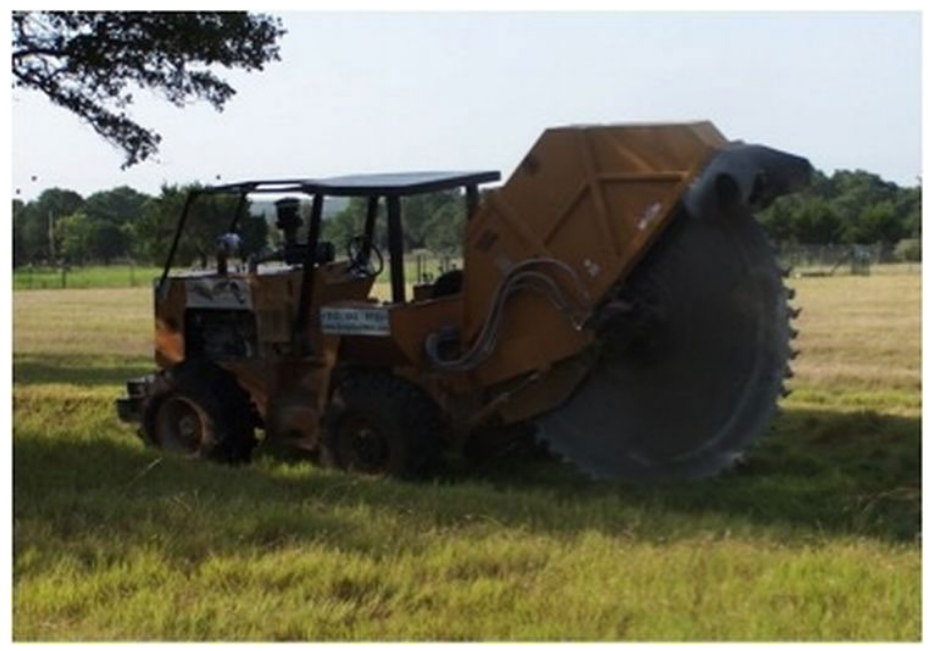

Figure 6. Rock saw 


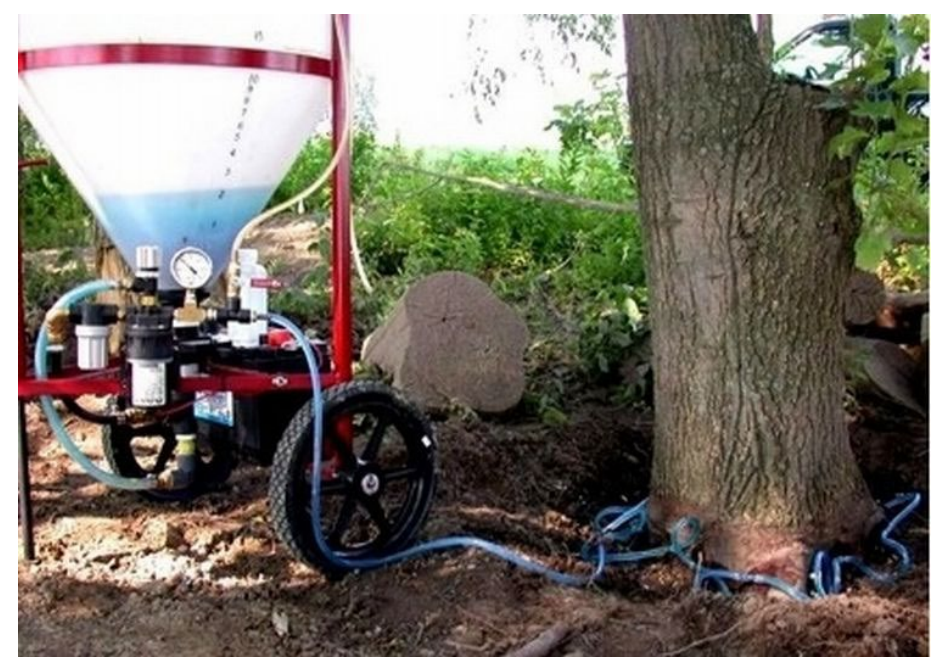

Figure 7. Chemical injection apparatus: propiconazole is administered through holes drilled into the root flares of a northern red oak.

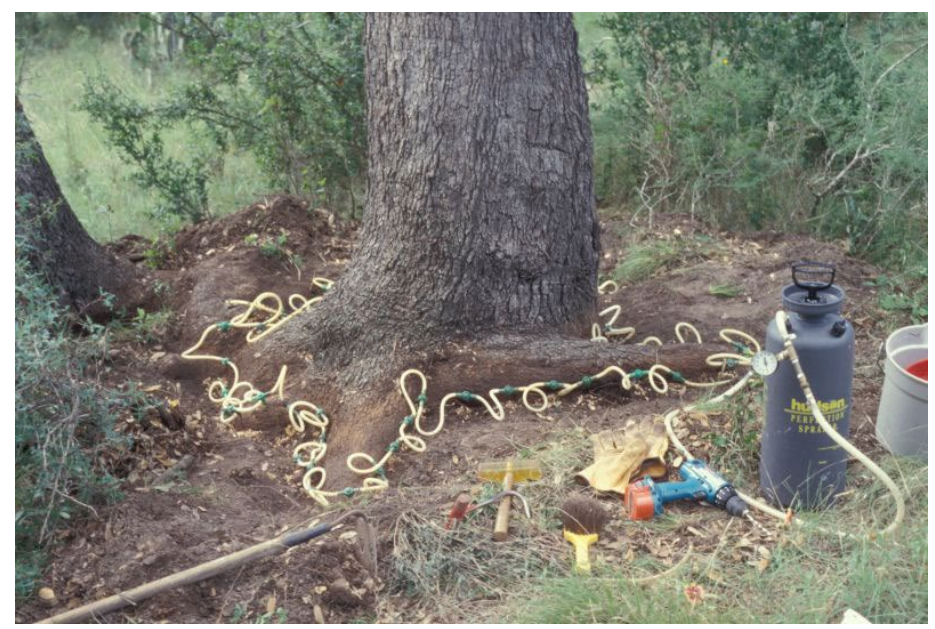

Figure 8. Injection of propiconazole into root flares of a live oak. Credits: David Appel, Texas A\&M University.

\section{Implications for Florida}

The oak species at greatest risk in Florida are those belonging to the red oak group (most easily identified by having leaves with pointed lobes) and live oaks (Q. virginiana). Popular landscape trees such as live oaks, laurel oaks, Shumard oaks, and willow oaks are especially at risk, primarily in areas where trees are planted in close proximity and/or where trees add significant value to the landscape. Live oaks, particularly those comprising oak hammocks, are especially vulnerable to root spread of the pathogen since many trunks are typically supported by a single root system (Appel 1995b).

Precautionary measures should be taken to minimize the risk of introduction into the state. The most likely introduction of the pathogen would be through movement of infected firewood from states where oak wilt is known to occur; therefore, continued public education (including posted notices) regarding the risks of moving wood between locales is vital. Firewood cut from potentially infected trees may also be treated to hasten drying (such as debarking and/or splitting) to curtail fungal mat production and then should be covered completely to prevent insect visitation. Rapid identification of new infection centers is crucial for containment of the pathogen. Classic oak wilt symptoms include premature leaf drop and wilting leaves turning bronze or brown around the perimeter (red oaks) or along leaf veins (live oaks). On red oaks, wilting typically begins in the topmost crown and rapidly progresses downwards, while on live oaks symptoms commonly progress branch by branch.

Other pests can cause similar symptoms on oak, such as the two-lined chestnut borer or oak anthracnose; however, these can usually be confirmed by visual inspection of the tree. If oak wilt is suspected, branch samples greater than 1 inch in diameter should be collected before complete wilt of the branch has occurred. Samples should be kept cool and sent to an appropriate lab for diagnostics.

\section{Literature Cited}

Appel, D. N. 1995a. Chemical control of oak wilt. Pages 81-88 in: Oak Wilt Perspectives: The Proceedings of the National Oak Wilt Symposium. D. N. Appel and R. F. Billings, eds. Information Development Inc., Houston, TX.

Appel, D. N. 1995b. The oak wilt enigma: Perspectives from the Texas epidemic. Annual Review of Phytopathology 33:103-118.

Beckman, C. H., J. E. Kuntz, A. J. Riker, and J. G. Berbee. 1953. Host responses associated with the development of oak wilt. Phytopathology 43(8):448-454.

Billings, R. 2008. The Texas Cooperative Oak Wilt Suppression Project: Lessons learned in the first twenty years. Pages 221-236 in The Proceedings of the 2nd National Oak Wilt Symposium. R. F. Billings and D. N. Appel, eds.

Bruhn, J. N., J. B. Pickens, and D. B. Stanfield. 1991. Probit analysis of oak wilt transmission through root grafts in red oak stands. Forest Science 37(1):28-44.

Camilli, K., D. Appel, and T. Watson. 2008. Studies on pruning cuts and wound dressings for oak control. Pages 121-134 in The Proceedings of the 2nd National Oak Wilt Symposium. R. F. Billings and D. N. Appel, eds. 
Eggers, J., J. Juzwik, S. Bernick, and L. Mordaunt. 2005.

Evaluation of propiconazole operational treatments of oaks for oak wilt control. USDA Forest Service North Central Research Station Research Note NC-390 6 pgs.

Hayslett, M., J. Juzwik, B. Molten, D. Appel, and K. Camilli. 2008. Insect vectors of the oak wilt fungus in Missouri and Texas. Pages 109-120 in The Proceedings of the 2nd National Oak Wilt Symposium. R. F. Billings and D. N. Appel, eds.

Juzwik, J., S. Cook, L. Haugen, and J. Elwell. 2004. Oak wilt: People and trees, a community approach to management. USDA Forest Service General Technical Report. NC-240.

O’Brien, J., M. Mielke, D. Starkey, and J. Juzwik. 2000. How to identify, prevent, and control oak wilt. NA-PR-03-00. USDA Forest Service Northeastern Area State and private Forestry, St. Paul, MN.

Osterbauer, N. K., and D. W. French. 1992. Propiconazole as a treatment for oak wilt in Quercus rubra and Q. ellipsoidalis. Journal of Arboriculture 18(5):221-226.

Osterbauer, N. K., T. Salisbury., and D. W. French. 1994. Propiconazole as a treatment for oak wilt in Quercus alba and Q. macrocarpa. Journal of Arboriculture 20(3):202.

Sachs, I. B., V. M. G. Nair, and J. E. Kuntz. 1970. Penetration and degradation of cell walls in oaks infected with Ceratocystis fagacearum. Phytopathology 60:1399-1404.

Struckmeyer, B. E., C. H. Beckman, J. E. Kuntz, and A. J. Riker. 1954. Plugging of vessels by tyloses and gums in wilting oaks. Phytopathology 44(3):148-153. 